\title{
T-cell Receptor Excision Circles in Newborns with Heart Defects
}

\author{
Kiran A. Gul ${ }^{1,5}$ (D) Janne Strand ${ }^{2} \cdot$ Rolf D. Pettersen ${ }^{2} \cdot$ Henrik Brun ${ }^{3} \cdot$ Tore G. Abrahamsen $^{4,5}$
}

Received: 28 September 2019 / Accepted: 13 February 2020 / Published online: 13 March 2020

(c) The Author(s) 2020

\begin{abstract}
In the fetus, the cardiac neural crest gives rise to both the thymus and the conotruncus of the heart. In newborn screening for severe T-cell lymphopenia neonates with congenital heart defects may be detected. In this study, we investigated the occurrence of T-cell lymphopenia in neonates with or without 22q11.2 deletion syndrome (del) suffering from heart defects. This retrospective cohort study included 125 patients with heart defects. T-cell receptor excision circles (TRECs), a measure for T-cell lymphopenia, were quantified by RT-PCR using stored newborn screening blood spots. Three patient groups were compared: non-conotruncal defects $(n=57)$, conotruncal defects $(n=42)$, and 22q11.2 del with conotruncal defects $(n=26)$. Significantly lower TREC values were detected in patients with 22q11.2 del and conotruncal heart defects compared to those with non-syndromic conotruncal $(p<0.001)$ and non-conotruncal $(p<0.001)$ defects. In contrast, no significant difference was found between patients with non-syndromic conotruncal and non-conotruncal heart defects $(p=0.152)$. Low TREC levels were obtained in neonates treated with heart surgery/intervention within 2 weeks after birth and in those with a fatal outcome $(p=0.02)$ independent of patient group. A correlation was found between low TREC numbers and oxygen saturation, $\mathrm{SpO}_{2}$ below $95 \%$ ( $p=0.017$ ). The $\mathrm{SpO}_{2}$ was significantly lower in the non-syndromic conotruncal group compared to non-conotruncal $(p<0.001)$ and 22q11.2 del group $(p=0.015)$. No correlation was found between low neonatal TRECs and infections needing hospitalization later in life $(p=0.135)$. Patients with 22q11.2 del and conotruncal defects have significantly lower TREC levels compared to patients with heart defects without this syndrome.
\end{abstract}

Keywords T-cell receptor excision circles $\cdot$ T-cell lymphopenia $\cdot$ Conotruncus $\cdot$ Conotruncal heart defects $\cdot$ Neural crest . 22q11.2 deletion syndrome

\section{Abbreviations}

ASD Atrial septal defect

CGH array Comparative genomic hybridization array

Del Deletion syndrome

FISH Fluorescent in situ hybridization

Kiran A. Gul

Kiran.aftab.gul@gmail.com

1 Department of Paediatric Research, Division of Paediatric and Adolescent Medicine, Oslo University Hospital Rikshospitalet, Oslo, Norway

2 Norwegian National Unit for Newborn Screening, Division of Paediatric and Adolescent Medicine, Oslo University Hospital Rikshospitalet, Oslo, Norway

3 Department of Paediatric Cardiology, Division of Paediatric and Adolescent Medicine, Oslo University Hospital Rikshospitalet, Oslo, Norway

4 Centre for Rare Disorders, Division of Paediatric and Adolescent Medicine, Oslo University Hospital, Oslo, Norway

5 Faculty of Medicine, University of Oslo, Oslo, Norway

$\begin{array}{ll}\text { IAA } & \text { Interrupted aortic arch } \\ \text { NBS } & \text { Newborn screening } \\ \text { NICUs } & \text { Neonatal intensive care units } \\ \text { PA } & \text { Pulmonary atresia } \\ \text { SCID } & \text { Severe combined immunodeficiency } \\ \text { TA } & \text { Truncus arteriosus } \\ \text { TCR } & \text { T-cell receptor } \\ \text { TCL } & \text { T-cell lymphopenia } \\ \text { TOF } & \text { Tetralogy of Fallot } \\ \text { TREC } & \text { T-cell receptor excision circle } \\ \text { VSD } & \text { Ventricular septal defect } \\ \text { SpO }_{2} & \text { Oxygen saturation }\end{array}$

\section{Introduction}

T-cell lymphopenia in neonates with congenital heart defects occurring as part of a syndrome or as a non-syndromic condition, has been described in a number of studies $[1,2]$. Newborn screening (NBS) for severe combined 
immunodeficiency (SCID) is now performed routinely in the USA and other countries including Norway. In this screening, both SCID and non-SCID conditions with T-cell lymphopenia are detected when determining T-cell receptor excision circles (TRECs). After screening 3 million newborns in ten American States, Kwan et al. [1] found an incidence of non-SCID T-cell lymphopenia of 1 in 14,000. Heart defects were found in $7 \%$ of these patients [1]. Congenital syndromes associated with T-cell lymphopenia, as the 22q11.2 deletion syndrome (del) and trisomy 21 (Down syndrome) were reported in $33 \%$ of these infants.

The incidence of congenital heart defects is approximately 1 in 100 [3]. Conotruncal heart defects, also known as outflow tract defects, represent $10-15 \%[3,4]$. They include severe conditions such as transposition of the great arteries, tetralogy of Fallot (TOF), double outlet right ventricle, interrupted aortic arch (IAA), pulmonary atresia (PA), truncus arteriosus (TA), and Conoventricular septal defects [5]. The conotruncal defects are often found in chromosomal syndromes [6] with 22q11.2 del occurring in 18\% [7]. In a previous study, we tested 46 patients with 22 q11.2 del and found that those with the lowest neonatal TREC numbers had the most severe heart defects [8]. In the present study, we wanted to compare the newborn TREC values in patients with non-conotruncal, non-syndromic conotruncal, and 22q11.2 del with conotruncal heart defects in order to study the effect of this chromosome microdeletion on the T-cell lymphopenia.

\section{Materials and Methods}

\section{Patients and Samples}

The patients invited to the study were identified through a registry of heart defects at the Oslo University Hospital. Our hospital has a national service for children with congenital heart defects which includes preoperative assessment and definitive treatment. Invitation letters were sent to 230 parents of children with heart defects, and $140(61 \%)$ consented to participate. The rest did not respond to the invitation. One patient with Noonan's syndrome and one with Turner's syndrome were excluded from the study. In two patients, no screening card was available. In the non-syndromic conotruncal heart defect group, only patients with a negative genetic test for 22q11.2 del were included. We finally studied 125 patients born after 2005 . They were diagnosed with non-syndromic conotruncal $(n=42)$, non-conotruncal $(n=57)$, or 22q11.2 del with conotruncal heart defects $(n=26)$. The 22q11.2 deletion was diagnosed by fluorescent in situ hybridization (FISH, $n=8$ ), multiplex ligationdependent probe amplification (MLPA, $n=16$ ), or comparative genomic hybridization array (CGH array, $n=2$ ).
Filter cards stored at a temperature between $-20{ }^{\circ} \mathrm{C}$ and $-25^{\circ} \mathrm{C}$ were retrieved from the National newborn screening diagnostic biobank (Oslo University Hospital, Norway).

Patient medical records were obtained from the hospitals, and a review was conducted by the first author. Data were collected, including the type of cardiac defects, treatment procedure (surgery/ intervention), gestational age, delivery mode, the identification of a syndrome diagnosis, and information about hospitalization due to infection later in life. $\mathrm{SpO}_{2}$ values before operation/intervention, measured by pulse oximetry, were also retrieved.

\section{TREC Test}

We used TREC levels as marker for T-cell lymphopenia [1, 9]. TRECs are circular DNA fragments generated during the sequential rearrangement of variable $\mathrm{V}, \mathrm{D}$, and $\mathrm{J}$ segments of T-cell receptor (TCR) genes [10]. These DNA circles do not replicate and will, therefore, be diluted after each cell division of $\mathrm{T}$ cells when they have emigrated from the thymus [11].

\section{Extraction of DNA}

DNA extraction was performed in a 96-well format. One $3.2 \mathrm{~mm}$ dried blood spot of each patient's screening card was punched into a 96-well PCR plate (VWR) using a Panthera puncher (PerkinElmer). $150 \mu \mathrm{L}$ Generation DNA elution solution (Qiagen) was added to each well, and the samples were incubated at $60{ }^{\circ} \mathrm{C}$ for $10 \mathrm{~min}$ on a microplate shaker (Eppendorf) at $1000 \mathrm{rpm}$. The supernatant was discarded, and the DNA was extracted in $100 \mu \mathrm{L}$ Generation DNA elution solution by incubation at $100{ }^{\circ} \mathrm{C}$ for $30 \mathrm{~min}$ in a PCR instrument.

\section{TREC qRT-PCR}

TREC and $\beta$-actin qPCR reactions were run in final volumes of $20 \mu \mathrm{L}$ containing $10 \mu \mathrm{L}$ PerfeCTa qPCR ToughMix (Quantabio), $500 \mathrm{nmol} / \mathrm{L}$ forward and reverse primers, $150 \mathrm{nmol} / \mathrm{L}$ probe, $0.4 \mathrm{mg} / \mathrm{mL}$ BSA and $8 \mu \mathrm{L}$ DNA $(4 \mu \mathrm{L}$ for the $\beta$-actin assay). The primer sequences are provided in Table 1. The reactions were carried out on a ViiA ${ }^{\mathrm{TM}} 7$ or QuantStudio7 Real-Time PCR system (Applied Biosystems) with the following program: $50{ }^{\circ} \mathrm{C}$ for $2 \mathrm{~min}, 95^{\circ} \mathrm{C}$ for $10 \mathrm{~min}$ followed by 45 cycles of $30 \mathrm{~s}$ at $95{ }^{\circ} \mathrm{C}$ and $60 \mathrm{~s}$ at $60{ }^{\circ} \mathrm{C}$.

Copy numbers were calculated based on standard curves generated from serially diluted plasmids kindly provided by Douek [12]. All the qPCR assessments fulfilled the quality requirements of similar slopes and with $R^{2}$ values $>0.99$. $\beta$-actin was used as a housekeeping gene to assure an adequate DNA extraction for PCR. Quality control was 
Table 1 Primers and probes used in the RT-PCR reactions

\begin{tabular}{ll}
\hline TREC forward & 5'-CAC ATC CCT TTC AAC CAT GCT-3' \\
TREC reverse & 5'GCC AGC TGC AGG GTT TAG G-3' \\
TREC probe & 5'-FAM-ACA CCT CTG GTT TTT GTA AAG \\
& GTG CCC ACT-3' TAMRA \\
$\beta$-actin forward & 5'-ATT TCC CTC TCA GGC ATG GA-3' \\
$\beta$-actin reverse & 5'-CGT CAC ACT TCA TGA TGG AGT TG-3' \\
$\beta$-actin probe & 5'- FAM-GTG GCA TCC ACG AAA CTA-3'- \\
& TAMRA \\
\hline
\end{tabular}

performed using TREC NBS QC provided by Center of Disease Control. The TREC value per $\mu \mathrm{L}$ was calculated assuming that a $3.2 \mathrm{~mm}$ punch contains $\sim 3 \mu \mathrm{L}$ of blood.

\section{Statistical Analysis}

One-way ANOVA was performed with post hoc Tukey test to compare TREC values or $\mathrm{SpO}_{2}$ values below $95 \%$ in patients with non-syndromic conotruncal, non-conotruncal, and $22 q 11.2$ del with conotruncal defects. The correlation between TREC groups (TREC quartiles) and heart surgery/ intervention within 2 weeks of life or death was done by using crosstabs and Chi-square Linear by linear association. For other clinical comparisons, student T test was employed. A significance level of 5\% was used. All figures were created using Graphpad prism.

\section{Results}

\section{TREC Values in Different Groups of Heart Defect}

The patients were divided in three groups, those with nonconotruncal $(n=57)$, conotruncal $(n=42)$, and $22 \mathrm{q} 11.2$ del with conotruncal heart defects $(n=26)$. The number of patients and the specified diagnoses are listed in Table 2. The mean number of TRECs was $323 / \mu \mathrm{L}$ in the non-conotruncal group, $270 / \mu \mathrm{L}$ in the conotruncal group, and $94 / \mu \mathrm{L}$ in the $22 q 11.2$ del group (Fig. 1, Table 3). Significantly lower number of TREC $(p<0.001)$ was found in the $22 \mathrm{q} 11.2 \mathrm{del}$ group compared to both non-syndromic conotruncal and to non-conotruncal heart defect groups. In the non-syndromic patients, a slight trend of lower TREC values was observed in the conotruncal group compared to non-conotruncal although not significant $(p=0.152)$. Lower TRECs were found in the $22 \mathrm{q} 11.2 \mathrm{del}$ group compared to the non-syndromic conotruncal group when investigating specific diagnoses such as TOF $(p<0.001)$, PA $(p=0.017)$, and IAA $(p=0.066)$.

\section{TREC Values and Heart Surgery/Intervention/Fatal Outcome}

In line with our previous study [8], the risk of death or heart surgery/intervention during the first 2 weeks of life decreased with increasing TREC values $(p=0.02)$. A

Table 2 TREC values in different heart defects

\begin{tabular}{|c|c|c|c|c|c|c|}
\hline & Non-conotruncal & $\mathrm{TREC} / \mu \mathrm{L}^{\mathrm{a}}$ & Conotruncal & $\mathrm{TREC} / \mu \mathrm{L}$ & $\begin{array}{l}22 \mathrm{q} 11.2 \text { del with } \\
\text { conotruncal }\end{array}$ & $\mathrm{TREC} / \mu \mathrm{L}$ \\
\hline \multirow[t]{7}{*}{ Heart defects } & $\begin{array}{l}\text { Atrioventricular septal } \\
\text { defect }\left(n^{\mathrm{b}}=1\right)\end{array}$ & 252 & Truncus arteriosus $(n=3)$ & $261(134-363)$ & Truncus arteriosus $(n=1)$ & 74 \\
\hline & $\begin{array}{l}\text { Atrial septal defect } \\
(n=25)\end{array}$ & $330(110-595)$ & $\begin{array}{l}\text { Transposition of the great } \\
\text { arteries }(n=19)\end{array}$ & $289(75-795)$ & $\begin{array}{l}\text { Simple septal defects } \\
(n=4)\end{array}$ & $143(84-241)$ \\
\hline & $\begin{array}{l}\text { Valvular pulmonary } \\
\text { stenosis }(n=14)\end{array}$ & $308(124-635)$ & $\begin{array}{l}\text { Tetralogy of fallot } \\
(n=5)\end{array}$ & $285(238-380)$ & Tetralogy of fallot $(n=8)$ & $71(23-215)$ \\
\hline & \multirow[t]{4}{*}{ Aortic stenosis $(n=17)$} & \multirow[t]{4}{*}{$331(75-627)$} & $\begin{array}{l}\text { Pulmonary atresia with } \\
\text { ventricular septal defect } \\
(n=5)\end{array}$ & $230(138-326)$ & $\begin{array}{l}\text { Pulmonary atresia with } \\
\text { ventricular septal defect } \\
(n=4)\end{array}$ & $74(84-161)$ \\
\hline & & & $\begin{array}{l}\text { Pulmonary atresia with- } \\
\text { out ventricular septal } \\
\text { defect }(n=3)\end{array}$ & $250(189-317)$ & $\begin{array}{l}\text { Pulmonary atresia with- } \\
\text { out ventricular septal } \\
\text { defect }(n=1)\end{array}$ & 53 \\
\hline & & & $\begin{array}{l}\text { Interrupted aortic arch } \\
\quad(n=6)\end{array}$ & $275(7-548)$ & $\begin{array}{l}\text { Interrupted aortic arch } \\
\quad(n=6)\end{array}$ & $113(0-190)$ \\
\hline & & & $\begin{array}{l}\text { Congenital corrected } \\
\text { transposition of the } \\
\text { great arteries }(n=1)\end{array}$ & 102 & $\begin{array}{l}\text { Absent pulmonary } \\
\text { valve, overriding aorta, } \\
\text { ventricular septal defect } \\
(n=1)\end{array}$ & 84 \\
\hline
\end{tabular}

${ }^{\mathrm{a}}$ Mean and range in each diagnosis

${ }^{\mathrm{b}}$ Number of patients 


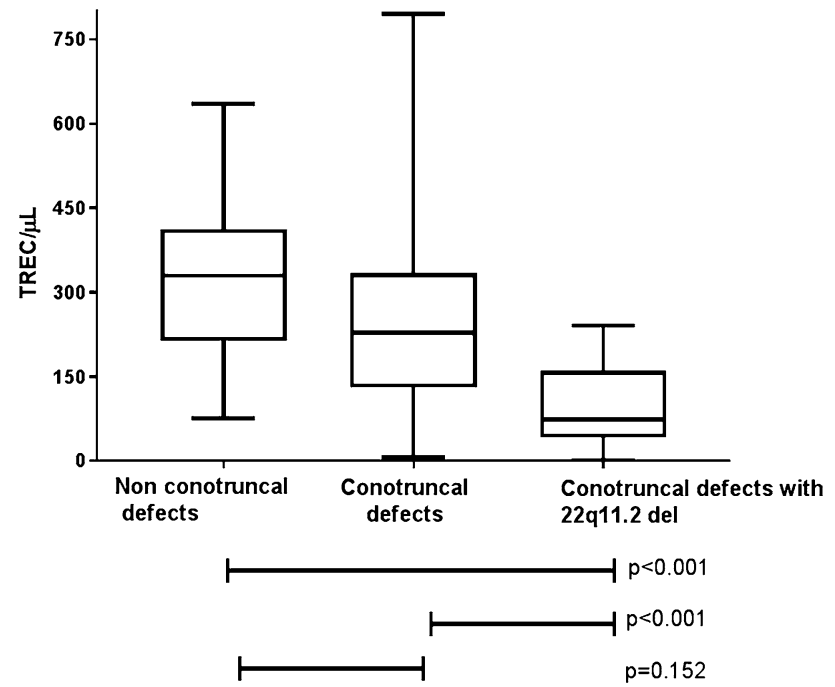

Fig. 1 TREC values in patients with heart defects

similar, but not so strong correlation was found if $22 \mathrm{q} 11.2$ del patients were excluded from the calculation $(p=0.041)$.

In 101 patients, we were able to collect neonatal $\mathrm{SpO}_{2}$ values preferably the first measurement after birth and obtained before heart surgery/intervention. A correlation was found between low TREC and $\mathrm{SpO}_{2}$ below 95\% $(p=0.017)$. The $\mathrm{SpO}_{2}$ was significantly lower in the conotruncal non-syndromic group $(p<0.001)$ and 22q11.2 del group $(p=0.002)$ compared to non-conotruncal heart defects group. In the conotruncal non-syndromic group, the $\mathrm{SpO}_{2}$ was significantly lower $(p=0.015)$ than in $22 \mathrm{q} 11.2 \mathrm{del}$.

\section{TREC Values and Prematurity, Birth Weight, and Delivery Mode}

Twelve of the patients were premature (Table 4), born in week 31-36. They had non-conotruncal $(n=6)$, conotruncal $(n=1)$ or 22q11.2 del with conotruncal $(n=5)$ heart defect, respectively. Exclusion of these patients gave similar TREC results (data not shown). Also, no association
Table 4 TREC values in premature infants, heart defect type, and diagnosis

\begin{tabular}{lllll}
\hline Heart defects & $\begin{array}{l}\text { Premature } \\
\text { infants }\end{array}$ & $\begin{array}{l}\text { Gesta- } \\
\text { tional age }\end{array}$ & $\begin{array}{l}\text { TREC } \\
\text { values/ } \mu \mathrm{L}\end{array}$ & Diagnosis \\
\hline Non-conotruncal & 1 & 34 & 120 & ASD \\
& 2 & 34 & 110 & ASD \\
& 3 & 36 & 220 & VPS \\
& 4 & 35 & 234 & ASD \\
& 5 & 34 & 302 & ASD \\
Conotruncal & 6 & 31 & 595 & ASD \\
Conotruncal with & 8 & 36 & 102 & CCTGA \\
22q11.2 del & 9 & 34 & 161 & PA, VSD \\
& 10 & 36 & 141 & IAA \\
& 11 & 34 & 36 & IAA \\
& 12 & 33 & 40 & PA, VSD \\
\hline
\end{tabular}

$A S D$ atrial septum defect, $C C T G A$ congenital corrected transposition of the great vessles, IAA interrupted aortic arch, $P A$ pulmonal atresi, $T A$ truncus arteriosus, TOF triade of Fallot, $V S D$ ventricular septum defect, $V P S$ valvular pulmonal stenosis

was found between TRECs and birth weight (below or above $2500 \mathrm{~g}$, data not shown) or delivery mode ( $n=110$, vaginal vs cesarean).

\section{TREC Values and Infections}

No association ( $n=103$ ) was found between the newborn TREC value and serious infections occurring later in life. The number of patients hospitalized due to infections is presented in Table 3. These patients were up to 8 years old. No association was found.
Table 3 Characteristics of the patient cohorts with heart defects

\begin{tabular}{llll}
\hline & Non-conotruncal & Conotruncal & $\begin{array}{l}\text { 22q11.2 del } \\
\text { with conotrun- } \\
\text { cal }\end{array}$ \\
\hline Mean TREC & $323{\mathrm{TREC} / \mu \mathrm{L}^{\mathrm{a}}}^{\mathrm{a}}$ & $270 \mathrm{TREC} / \mu \mathrm{L}$ & $94 \mathrm{TREC} / \mu \mathrm{L}$ \\
Operated within 14 days & $10^{\mathrm{b}}$ & 35 & 12 \\
Died & 0 & 3 & 4 \\
Hospitalization due to infections & $13 / 47^{\mathrm{c}}$ & $17 / 31$ & $14 / 25$ \\
\hline
\end{tabular}

${ }^{\mathrm{a}}$ Mean values in each group

${ }^{\mathrm{b}}$ Number of patients

${ }^{\mathrm{c}}$ Number of patients with information available 


\section{Discussion}

\section{TREC Values in Different Heart Defects}

We found significantly lower number of TRECs in 22q11.2 del patients with conotruncal heart defects compared to patients with conotruncal and non-conotruncal defects without this syndrome. Non-syndromic patients with conotruncal defects had a tendency, although not significant, of lower TREC values than those with non-conotruncal defects. In line with our results Sullivan et al. [13] found lower absolute lymphocyte counts and CD3, CD4 and CD8 T-cell counts in neonates (median age 17 days) with 22q11.2 del and cardiac anomalies when compared to controls with cardiac defects.

We also compared the TREC values in neonates with and without the syndrome, suffering from different groups of conotruncal heart defects (TOF, PA and IAA). We found significantly lower TREC values in TOF and PA patients with 22 q11.2 del. Sullivan et al. [14] studied 43 children (above 6 months of age) with 22q11.2 del and 5 distinct cardiac anomalies and found no correlation between T-cell lymphopenia and the specific cardiac anomaly. In another study [15] they investigated a larger group of patients $(n=353)$ with 22q11.2 del. They found no correlation between T-cell numbers and the severity of cardiac anomaly (divided in three groups, according to need for operation) or the complexity of the surgical procedure.

In this respect the common embryology of the heart and the thymus is interesting. The thymus develops from the 3rd pharyngeal pouch endoderm and cardiac neural crest cells $[16,17]$. The latter cells also give rise to the outflow tract of the heart with aortic arches and the aorta and pulmonary arteries [18]. Kirby et al. [19, 20] demonstrated that ablation of the cardiac neural crest in chick embryos leads to hypoplasia/aplasia of the thymus, defective development of the cardiac outflow tract resulting in conotruncal defects. Also in mice disruption of the cardiac neural crest migration causes many of the 22q11.2 del features such as thymus hypoplasia/aplasia and conotruncal heart defects [21]. Patients with 22q11.2 del usually have a haploinsufficiency of the TBX1 gene [22]. This gene encodes a transcription factor which is important for the migration of the neural crest cells into the 3rd and 4th pharyngeal arches and pouches.

\section{TREC Values and Heart Surgery/Intervention/Fatal Outcome}

Dar et al. [23] compared 22q11.2 del patients with and without heart surgery and found no correlation between low TREC levels and need for heart surgery. However, in our study we found an increased risk of heart surgery/ intervention or death within 2 weeks after birth in patients with lowest TREC values. Neonates requiring early heart surgery/intervention or having a fatal outcome may have physical and emotional stress that activates the hypothalamus-pituitary-adrenal (HPA) axis. This may lead to an increased production of cortisol and cause thymus involution and reduction in thymopoiesis [24, 25].

In animal models, cyanotic heart disease causing hypoxia has been found to increase endogenous glucocorticoid production [26-28]. This may in part be the reason for the lower TRECs in the conotruncal heart defect group as compared to the non-conotruncal group. This is supported by our finding of low TRECs when $\mathrm{SpO}_{2}$ is below 95\%. However, the $\mathrm{SpO}_{2}$ was significantly lower in non-syndromic conotruncal heart defects compared to patients with 22q11.2 del. This suggests that stress alone cannot explain the low TRECs in 22q11.2 del group, and a study of 29 infants with chronic hypoxia due to cyanotic congenital heart disease, did not show any effect on the HPA axis [29]. However, in the T-cell lymphopenia (TCL) screening, higher rates of abnormal screen are seen in the premature and critical ill infants [30]. Gerstel-Thompson [31] demonstrated that higher proportion of infants in neonatal intensive care units (NICUs) had lower TREC than non-NICU infants. Kwan et al. [30] described occurrence of non-SCID TCL in patients with congenital defects. This TCL improved when the defects were repaired. Suppression of the lymphopoiesis caused by stress may be one of the main reasons for TCL in this group [30]. A better marker for hypoxia could be serum lactic acid. Unfortunately we did not have such values available.

\section{TREC Values and Prematurity, Birth Weight, and Delivery Mode}

Previous studies have shown a correlation between prematurity and low TREC levels [32, 33]. TREC usually normalize with increasing gestational age. In our study, excluding the premature infants did not affect our findings. Furthermore, low birth weight or mode of delivery did not influence the TREC values, in contrast to what was reported in healthy children by Schlinzig et al. [34].

\section{TREC Values and Infection}

In 103 patients, we had information about later hospitalizations. As in our previous report [8], we did not find any association between low neonatal TREC levels for infections when they grew older. However, our study lacks information from general practitioners and parents about days off from day care institution/school. Therefore, we cannot totally 
exclude an association between infections in general and low TREC levels.

\section{Conclusion}

In the present study we have demonstrated that neonates with 22q11.2 del and conotruncal heart defects have significantly lower TREC levels than non-syndromic patients with conotruncal or non-conotruncal defects. This result indicates that T-cell lymphopenia (e.g., low TREC values) observed in the conotruncal heart defects is mainly due to the chromosome 22q11.2 deletion. However, the stress due to the conotruncal heart defects in either group may also affect thymus function and result in low TREC values.

Acknowledgements Open Access funding provided by Oslo University \& Oslo University Hospital. I want to acknowledge Marianne Wright for her suggestions in the Manuscript, Leiv Sandvik for his contributions as the statistician, and participating parents/patients and hospitals.

Authors Contributions KAG wrote the manuscript with support from all the authors. JS, prepared the samples and carried out the experiments. TGA was the main supervisor of the project. HB and RDP were assistant supervisors. All authors discussed the results and contributed to the final manuscript.

\section{Compliance with Ethical Standards}

Conflict of interest All authors declare that there are no conflict of interest.

Ethical Approval The study was approved by the Regional Committee for Research Ethics (2014/2239) and the Data Protection Officer of Oslo University Hospital.

Informed Consent Informed consent was obtained from parents of all participants.

Open Access This article is licensed under a Creative Commons Attribution 4.0 International License, which permits use, sharing, adaptation, distribution and reproduction in any medium or format, as long as you give appropriate credit to the original author(s) and the source, provide a link to the Creative Commons licence, and indicate if changes were made. The images or other third party material in this article are included in the article's Creative Commons licence, unless indicated otherwise in a credit line to the material. If material is not included in the article's Creative Commons licence and your intended use is not permitted by statutory regulation or exceeds the permitted use, you will need to obtain permission directly from the copyright holder. To view a copy of this licence, visit http://creativecommons.org/licenses/by/4.0/.

\section{References}

1. Kwan A, Abraham RS, Currier R, Brower A, Andruszewski K, Abbott JK, Baker M, Ballow M, Bartoshesky LE, Bonilla FA, Brokopp C, Brooks E, Caggana M, Celestin J, Church JA, Comeau
AM, Connelly JA, Cowan MJ, Cunningham-Rundles C, Dasu T, Dave N, De La Morena MT, Duffner U, Fong CT, Forbes L, Freedenberg D, Gelfand EW, Hale JE, Hanson IC, Hay BN, Hu D, Infante A, Johnson D, Kapoor N, Kay DM, Kohn DB, Lee R, Lehman H, Lin Z, Lorey F, Abdel-Mageed A, Manning A, McGhee S, Moore TB, Naides SJ, Notarangelo LD, Orange JS, Pai SY, Porteus M, Rodriguez R, Romberg N, Routes J, Ruehle M, Rubenstein A, Saavedra-Matiz CA, Scott G, Scott PM, Secord E, Seroogy C, Shearer WT, Siegel S, Silvers SK, Stiehm ER, Sugerman RW, Sullivan JL, Tanksley S, Tierce ML, Verbsky J, Vogel B, Walker R, Walkovich K, Walter JE, Wasserman RL, Watson MS, Weinberg GA, Weiner LB, Wood H, Yates AB, Puck JM, Bonagura VR (2014) Newborn screening for severe combined immunodeficiency in 11 screening programs in the United States. JAMA 312(7):729-738. https://doi.org/10.1001/jama.2014.9132

2. Amatuni GS, Currier RJ, Church JA, Bishop T, Grimbacher E, Nguyen AA, Agarwal-Hashmi R, Aznar CP, Butte MJ, Cowan MJ, Dorsey MJ, Dvorak CC, Kapoor N, Kohn DB, Markert ML, Moore TB, Naides SJ, Sciortino S, Feuchtbaum L, Koupaei RA, Puck JM (2019) Newborn screening for severe combined immunodeficiency and T-cell lymphopenia in California, 2010-2017. Pediatrics. https://doi.org/10.1542/peds.2018-2300

3. Botto LD, Correa A, Erickson JD (2001) Racial and temporal variations in the prevalence of heart defects. Pediatrics 107(3):E32

4. O'Malley CD, Shaw GM, Wasserman CR, Lammer EJ (1996) Epidemiologic characteristics of conotruncal heart defects in California, 1987-1988. Teratology 53(6):374-377. https://doi. org/10.1002/(sici)1096-9926(199606)53:6\%3c374:aid-tera8 \%3e3.0.co;2-\#

5. Botto LD, Lin AE, Riehle-Colarusso T, Malik S, Correa A (2007) Seeking causes: classifying and evaluating congenital heart defects in etiologic studies. Birth Defects Res A Clin Mol Teratol 79(10):714-727. https://doi.org/10.1002/bdra.20403

6. Ferencz C, Neill CA, Boughman JA, Rubin JD, Brenner JI, Perry LW (1989) Congenital cardiovascular malformations associated with chromosome abnormalities: an epidemiologic study. J Pediatr 114(1):79-86

7. Carotti A, Digilio MC, Piacentini G, Saffirio C, Di Donato RM, Marino B (2008) Cardiac defects and results of cardiac surgery in 22q11.2 deletion syndrome. Developmental disabilities research reviews 14(1):35-42. https://doi.org/10.1002/ddrr.6

8. Gul KA, Overland T, Osnes L, Baumbusch LO, Pettersen RD, Lima K, Abrahamsen TG (2015) Neonatal levels of T-cell receptor excision circles (TREC) in patients with 22q11.2 deletion syndrome and later disease features. J Clin Immunol. https://doi. org/10.1007/s10875-015-0153-5

9. Chan K, Puck JM (2005) Development of population-based newborn screening for severe combined immunodeficiency. J Allergy Clin Immunol 115(2):391-398. https://doi.org/10.1016/j. jaci.2004.10.012

10. Livak F, Schatz DG (1996) T-cell receptor alpha locus V(D) $\mathrm{J}$ recombination by-products are abundant in thymocytes and mature T cells. Mol Cell Biol 16(2):609-618

11. Hazenberg MD, Otto SA, Cohen Stuart JW, Verschuren MC, Borleffs JC, Boucher CA, Coutinho RA, Lange JM, Rinke de Wit TF, Tsegaye A, van Dongen JJ, Hamann D, de Boer RJ, Miedema F (2000) Increased cell division but not thymic dysfunction rapidly affects the T-cell receptor excision circle content of the naive $\mathrm{T}$ cell population in HIV-1 infection. Nat Med 6(9):1036-1042. https://doi.org/10.1038/79549

12. Douek DC, McFarland RD, Keiser PH, Gage EA, Massey JM, Haynes BF, Polis MA, Haase AT, Feinberg MB, Sullivan JL, Jamieson BD, Zack JA, Picker LJ, Koup RA (1998) Changes in thymic function with age and during the treatment of HIV infection. Nature 396(6712):690-695. https://doi.org/10.1038/25374 
13. Sullivan KE, McDonald-McGinn D, Driscoll DA, Emanuel BS, Zackai EH, Jawad AF (1999) Longitudinal analysis of lymphocyte function and numbers in the first year of life in chromosome 22q11.2 deletion syndrome (DiGeorge syndrome/velocardiofacial syndrome). Clin Diagn Lab Immunol 6(6):906-911

14. Sullivan KE, Jawad AF, Randall P, Driscoll DA, Emanuel BS, McDonald-McGinn DM, Zackai EH (1998) Lack of correlation between impaired $\mathrm{T}$ cell production, immunodeficiency, and other phenotypic features in chromosome 22q11.2 deletion syndromes. Clin Immunol Immunopathol 86(2):141-146

15. Sullivan KE, Crowley TB, Maurer K, Goldmuntz E, Gaynor JW, Zackai E, McDonald-McGinn D (2018) T-cell lymphopenia in $22 \mathrm{q} 11.2$ deletion syndrome: relationship to cardiac disease. J Allergy Clin Immunol. 6(2):690-691. https://doi.org/10.1016/j. jaip.2017.08.028

16. Gordon J, Manley NR (2011) Mechanisms of thymus organogenesis and morphogenesis. Development 138(18):3865-3878. https ://doi.org/10.1242/dev.059998

17. Grapin-Botton A, Constam D (2007) Evolution of the mechanisms and molecular control of endoderm formation. Mech Dev 124(4):253-278. https://doi.org/10.1016/j.mod.2007.01.001

18. Gittenberger-de Groot AC, Bartelings MM, Deruiter MC, Poelmann RE (2005) Basics of cardiac development for the understanding of congenital heart malformations. Pediatr Res 57(2):169-176. https://doi.org/10.1203/01.pdr.0000148710.69159 .61

19. Bockman DE, Redmond ME, Waldo K, Davis H, Kirby ML (1987) Effect of neural crest ablation on development of the heart and arch arteries in the chick. Am J Anat 180(4):332-341. https ://doi.org/10.1002/aja.1001800403

20. Kirby ML, Turnage KL 3rd, Hays BM (1985) Characterization of conotruncal malformations following ablation of "cardiac" neural crest. Anat Rec 213(1):87-93. https://doi.org/10.1002/ar.10921 30112

21. Lindsay EA, Vitelli F, Su H, Morishima M, Huynh T, Pramparo T, Jurecic V, Ogunrinu G, Sutherland HF, Scambler PJ, Bradley A, Baldini A (2001) Tbx1 haploinsufficieny in the DiGeorge syndrome region causes aortic arch defects in mice. Nature 410(6824):97-101. https://doi.org/10.1038/35065105

22. Merscher S, Funke B, Epstein JA, Heyer J, Puech A, Lu MM, Xavier RJ, Demay MB, Russell RG, Factor S, Tokooya K, Jore BS, Lopez M, Pandita RK, Lia M, Carrion D, Xu H, Schorle H, Kobler JB, Scambler P, Wynshaw-Boris A, Skoultchi AI, Morrow BE, Kucherlapati R (2001) TBX1 is responsible for cardiovascular defects in velo-cardio-facial/DiGeorge syndrome. Cell 104(4):619-629

23. Dar N, Gothelf D, Korn D, Frisch A, Weizman A, Michaelovsky E, Carmel M, Yeshayahu Y, Dubnov-Raz G, Pessach IM, Simon AJ, Lev A, Somech R (2015) Thymic and bone marrow output in individuals with 22q112 deletion syndrome. Pediatr Res 77(4):579-585. https://doi.org/10.1038/pr.2015.14

24. Haynes BF, Markert ML, Sempowski GD, Patel DD, Hale LP (2000) The role of the thymus in immune reconstitution in aging, bone marrow transplantation, and HIV-1 infection. Annu Rev Immunol 18:529-560. https://doi.org/10.1146/annurev.immun ol.18.1.529
25. Eriksen HB, Biering-Sorensen S, Lund N, Correia C, Rodrigues A, Andersen A, Ravn H, Aaby P, Jeppesen DL, Benn CS (2014) Factors associated with thymic size at birth among low and normal birth-weight infants. J Pediatr 165(4):713-721. https://doi. org/10.1016/j.jpeds.2014.06.051

26. Bruder ED, Taylor JK, Kamer KJ, Raff H (2008) Development of the ACTH and corticosterone response to acute hypoxia in the neonatal rat. Am J Physiol Regul Integr Comp Physiol 295(4):R1195-1203. https://doi.org/10.1152/ajpregu.90400.2008

27. Raff H, Lee JJ, Widmaier EP, Oaks MK, Engeland WC (2004) Basal and adrenocorticotropin-stimulated corticosterone in the neonatal rat exposed to hypoxia from birth: modulation by chemical sympathectomy. Endocrinology 145(1):79-86. https://doi. org/10.1210/en.2003-1130

28. Fujimori K, Takanashi A, Endo C, Sato A (2008) Stress hormone responses during 24-hour hypoxemia in preterm goat fetus. Tohoku J Exp Med 215(2):189-197

29. Caprirolo G, Ghanayem NS, Murkowski K, Nugent ML, Simpson PM, Raff H (2013) Circadian rhythm of salivary cortisol in infants with congenital heart disease. Endocrine 43(1):214-218. https:// doi.org/10.1007/s 12020-012-9791-z

30. Kwan A, Church JA, Cowan MJ, Agarwal R, Kapoor N, Kohn DB, Lewis DB, McGhee SA, Moore TB, Stiehm ER, Porteus M, Aznar CP, Currier R, Lorey F, Puck JM (2013) Newborn screening for severe combined immunodeficiency and T-cell lymphopenia in California: results of the first 2 years. J Allergy Clin Immunol 132(1):140-150. https://doi.org/10.1016/j.jaci.2013.04.024

31. Gerstel-Thompson JL, Wilkey JF, Baptiste JC, Navas JS, Pai SY, Pass KA, Eaton RB, Comeau AM (2010) High-throughput multiplexed T-cell-receptor excision circle quantitative PCR assay with internal controls for detection of severe combined immunodeficiency in population-based newborn screening. Clin Chem 56(9):1466-1474. https://doi.org/10.1373/clinchem.2010.144915

32. Vogel BH, Bonagura V, Weinberg GA, Ballow M, Isabelle J, DiAntonio L, Parker A, Young A, Cunningham-Rundles C, Fong CT, Celestin J, Lehman H, Rubinstein A, Siegel S, Weiner L, Saavedra-Matiz C, Kay DM, Caggana M (2014) Newborn screening for SCID in New York State: experience from the first two years. J Clin Immunol 34(3):289-303. https://doi.org/10.1007/ s10875-014-0006-7

33. Routes JM, Grossman WJ, Verbsky J, Laessig RH, Hoffman GL, Brokopp CD, Baker MW (2009) Statewide newborn screening for severe T-cell lymphopenia. JAMA 302(22):2465-2470. https ://doi.org/10.1001/jama.2009.1806

34. Schlinzig T, Johansson S, Stephansson O, Hammarstrom L, Zetterstrom RH, von Dobeln U, Cnattingius S, Norman M (2017) Surge of immune cell formation at birth differs by mode of delivery and infant characteristics-A population-based cohort study. PLoS ONE 12(9):e0184748. https://doi.org/10.1371/journ al.pone. 0184748

Publisher's Note Springer Nature remains neutral with regard to jurisdictional claims in published maps and institutional affiliations. 